\title{
Synthesis of Octahedral-Shaped NiO and Approaches to an Anode Material of Manufactured Solid Oxide Fuel Cells Using the Decalcomania Method
}

\author{
Haeran Cho, ${ }^{1}$ Huryul Lee, ${ }^{2}$ Sun-Min Park, ${ }^{1}$ Byung-Hyun Choi, ${ }^{1}$ and Misook Kang ${ }^{2}$ \\ ${ }^{1}$ Korean Institutes of Ceramic Engineering \& Technology (KICET), Geumcheon-gu, Seoul 153-801, Republic of Korea \\ ${ }^{2}$ Department of Chemistry, College of Science, Yeungnam University, Gyeongsan, Gyeongbuk 712-749, Republic of Korea \\ Correspondence should be addressed to Misook Kang; mskang@ynu.ac.kr
}

Received 30 November 2012; Revised 25 February 2013; Accepted 17 March 2013

Academic Editor: Jie-Fang Zhu

Copyright ( $\odot 2013$ Haeran Cho et al. This is an open access article distributed under the Creative Commons Attribution License, which permits unrestricted use, distribution, and reproduction in any medium, provided the original work is properly cited.

Micrometer-sized and octahedral-shaped $\mathrm{NiO}$ particles were synthesized by microwave thermal treatment at 300 watt power for $15 \mathrm{~min}$ in a microwave chamber to be used as an anode material in solid oxide fuel cells. SEM image and particle size distribution revealed near-perfect octahedral $\mathrm{NiO}$ microparticle with sizes ranging from 4.0 11.0 $\mu \mathrm{m}$. The anode functional layer (AFL, $60 \mathrm{wt} \%$ $\mathrm{NiO}$ synthesized: commercial $40 \mathrm{wt} \% \mathrm{YSZ}$ ), electrolyte (commercial Yttria-stabilized zirconia, YSZ), and cathode (commercial $\mathrm{La}_{0.8} \mathrm{Sr}_{0.2} \mathrm{MnO}_{3}$, LSM) layers were manufactured using the decalcomania method on a porous anode support, sequentially. The sintered electrolyte at $1450^{\circ} \mathrm{C}$ for $2 \mathrm{~h}$ using the decalcomania method was dense and had a thickness of about $10 \mu \mathrm{m}$. The cathode was sintered at $1250^{\circ} \mathrm{C}$ for $2 \mathrm{~h}$, and it was porous. Using humidified hydrogen as a fuel, a coin cell with a $15 \mu \mathrm{m}$ thick anode functional layer exhibited maximum power densities of $0.28,0.38$, and $0.65 \mathrm{~W} / \mathrm{cm}^{2}$ at 700,750 , and $800^{\circ} \mathrm{C}$, respectively. Otherwise, when a commercial YSZ anode functional layer was used, the maximum power density was $0.55 \mathrm{~W} / \mathrm{cm}^{2}$ at $800^{\circ} \mathrm{C}$.

\section{Introduction}

Solid oxide fuel cells (SOFCs) consist entirely of metal oxides, $\mathrm{NiO}, \mathrm{YSZ}$, and LSM and have advantages of high efficiency and durability without expensive catalysts. However, it is difficult to control the size and shape of the ceramics produced because of many restrictions and complex geometries. In order to solve these problems, many researchers have studied means of maximizing reaction areas by changing stack sizes and developing new materials [1-5]. In many of these areas, SOFC fabrication methods are generally considered to be limiting factors based on considerations of automation and scalability [6]. Some SOFC structures are produced using traditional ceramic preparation methods, such as powder pressing, tape casting, screen printing, or conventional spray methods [7]. Other more sophisticated methods, such as plasma spraying $[8,9]$, vacuum deposition [10], and extrusion-based direct-write methods [11], have also been reported. Here, the decalcomania printing method is introduced. This method involves the transfer of designs from specially prepared paper to a wood or glass or metal surface. This method is expected to have some advantages because it is easy to prepare materials of the desired shape and size; manufacturing is straightforward. On the other hand, $\mathrm{NiO} / \mathrm{YSZ}$ is widely used as an anode material for SOFCs because it has sufficient electronic conductivity and a good catalytic reaction for fuel gas at its operating temperature. Generally, anode materials for SOFCs also should be thermally and chemically compatible compared with other component materials at operating and higher temperatures, because SOFCs operate in the temperature range $800 \sim 1000^{\circ} \mathrm{C}$. However, commercial NiO-loaded YSZ anode materials have a serious problem, because they are strongly deactivated during the operations of SOFCs, because of $\mathrm{NiO}$ aggregation at high temperature. Research into the synthesis of $\mathrm{NiO}$ nanoparticles has increased during the past decade and methods such as, sol-gel [12], microemulsion precipitation [13], chemical vapor deposition [14], and sputtering [15] have been designed. Recently, some researchers [16] have attempted to use advanced microwave treatments 


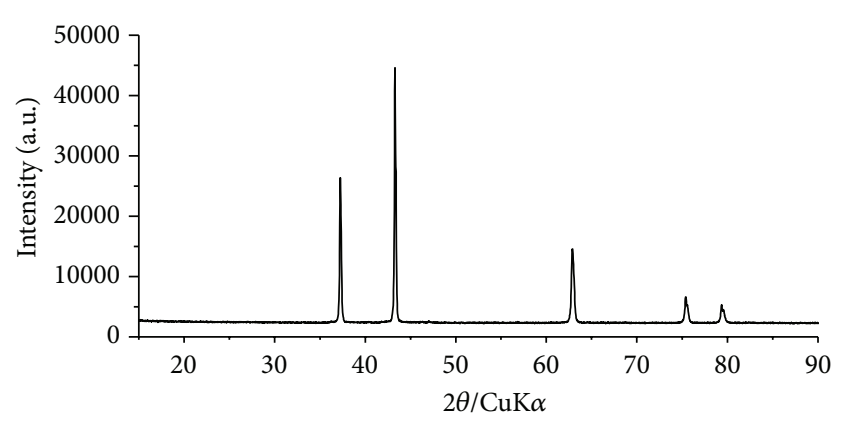

(a)

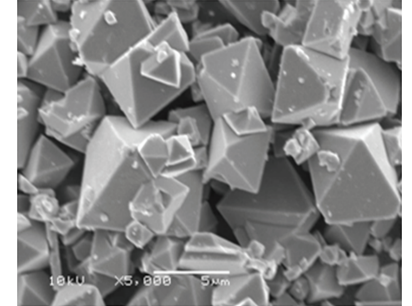

(b)

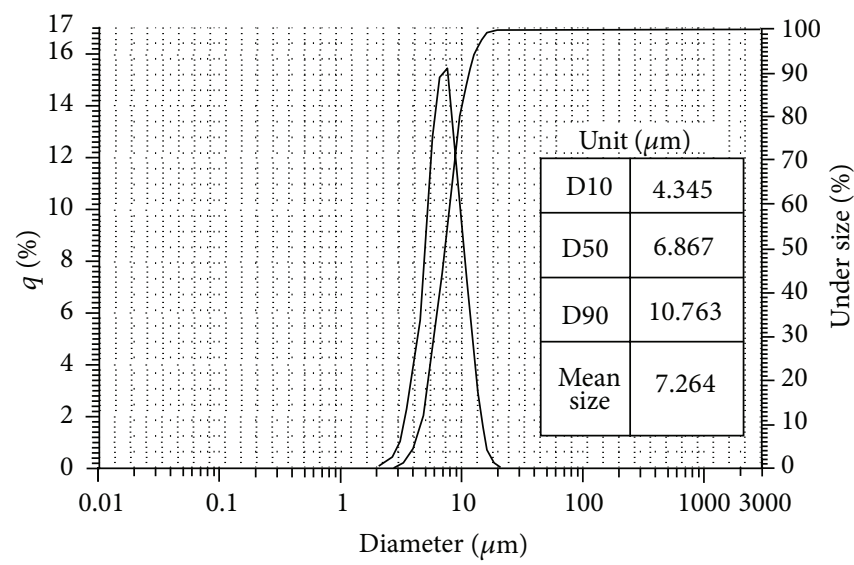

(c)

FIGURE 1: XRD pattern (a), SEM image (b), and particle size distribution (c) of the NiO powder synthesized using the microwave thermal treatment.

using various polymeric or surfactant additives to synthesize various metal materials with special morphologies. However, few studies have addressed the morphology for $\mathrm{NiO}$ as an anode material for SOFCs $[17,18]$. In this study, we examined the preparation of microsized octahedral $\mathrm{NiO}$ particles using a microwave thermal treatment. Microwave heating was found to increase densification and shortened sintering time as compared with conventional heating. The synthesized $\mathrm{NiO}$ was characterized by X-ray diffraction (XRD), transmission electron microscopy (SEM), particle size, and zeta potentials. In order to explore the applicability of decalcomania printing to SOFC materials, a traditional set of SOFC electrolytes were synthesized during this study. An anode of commercial Yttria-stabilized zirconia and a cathode of commercial $\mathrm{La}_{0.8} \mathrm{Sr}_{0.2} \mathrm{MnO}_{3}(1.0 \mu \mathrm{m}$, Tosho, Japan) were selected. The top and cross-section morphologies of a single cell were evaluated, and the electrochemical properties and the output of an SOFC single cell were measured under optimum conditions.

\section{Experimental}

2.1. Synthesis of Octahedral-Shaped Ni. The $\mathrm{NiO}$ was synthesized by the microwave thermal treatment method. The process used was as follows. First, after the addition of polystyrene (molecular weight $=10,000$, Aldrich, USA) and
Ni source $\left(\mathrm{NiCl}_{2} \cdot \mathrm{H}_{2} \mathrm{O}, 99.95 \%\right.$, Junsei Chemical, Japan) into ethanol, the solution was stirred homogeneously. The mixed solution was then placed in a quartz liner and the solution was microwave heated at $300 \mathrm{~W}$ for $15 \mathrm{~min}$. The product like a lump so obtained was then thermally treated at $450^{\circ} \mathrm{C}$ for $3 \mathrm{~h}$ to allow crystallization and remove polymer components. To prepare anode functional layers, we purchased a commercially available YSZ powder (TZ8Y, D50 $=3 \mu \mathrm{m}$, Tosoh, Japan). To prepare the synthesized NiO (60 wt $\%$ )/YSZ (40 wt\%) material, a physically mixing technique was used.

2.2. Characterization of Octahedral-Shaped NiO. The prepared $\mathrm{NiO}$ was subjected to powder XRD analysis (model MPD from PANalytical) using nickel-filtered $\mathrm{CuK} \alpha$ radiation $(30 \mathrm{kV}, 30 \mathrm{~mA})$ at 2-theta angles of $10-90$. The scan speed was $10^{\circ} / \mathrm{min}$, and the time constant was $1 \mathrm{~s}$. The sizes and shapes of microparticles were determined by FE-SEM (field emission scanning electron microscopy, SEM-S-4100, Hitachi) at $120 \mathrm{kV}$. The morphologies were observed using a scanning electron microscope. Particle sizes were determined using a particle size analyzer (LA-950V2, Horiba, Japan). Zeta potentials were determined by measuring electrophoretic mobility using an electrophoresis measurement apparatus (ELS 8000, Otsuka Electronics, Japan). Electrophoretic light scattering (ELS) determinations were performed in reference beam mode using a laser light source wavelength of $670 \mathrm{~nm}$, 


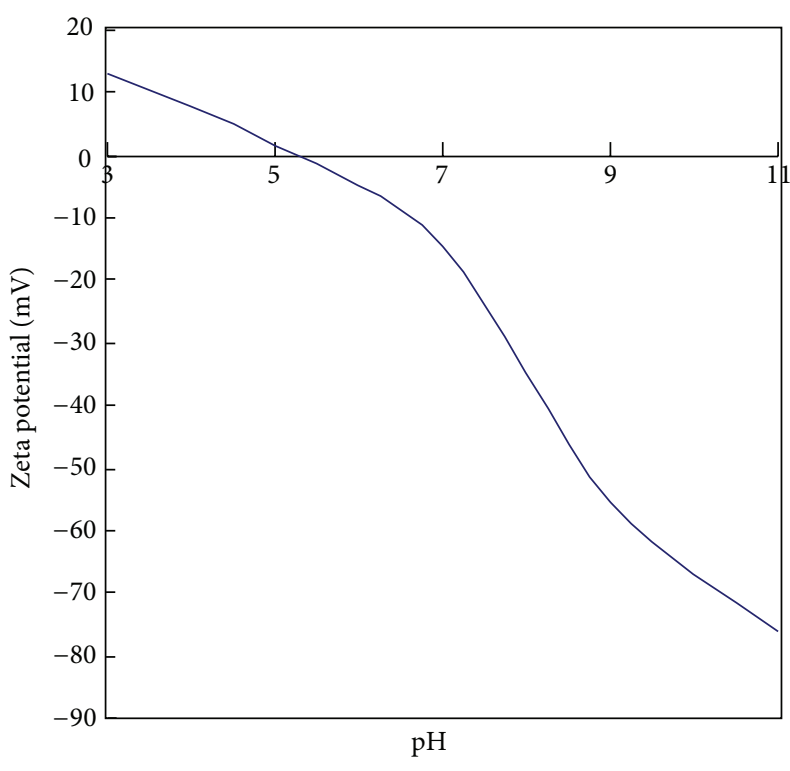

(a)

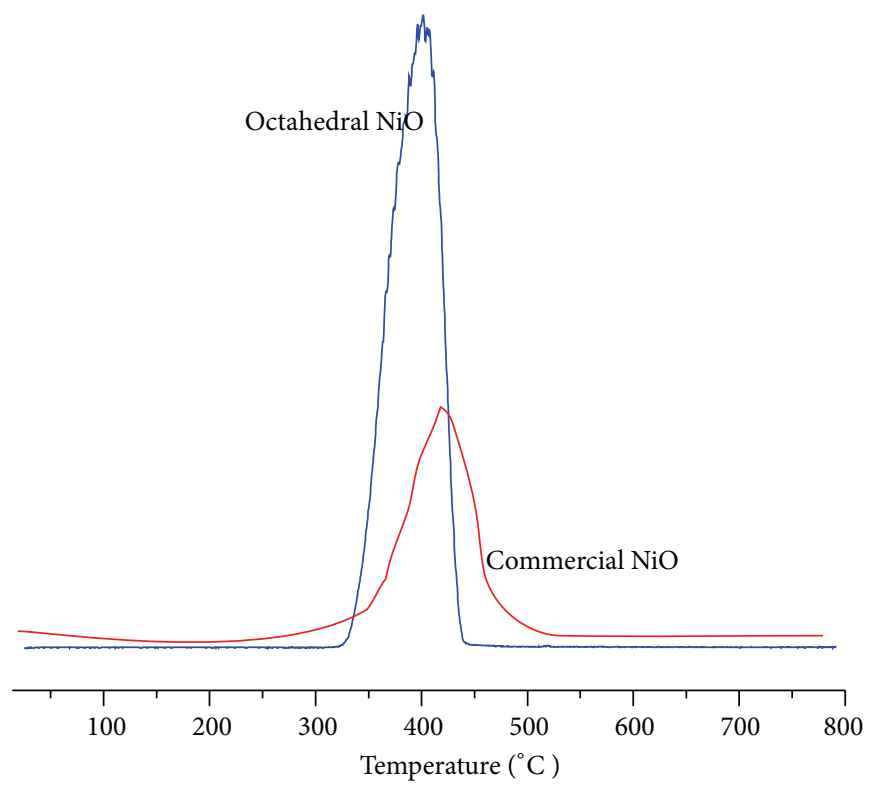

(b)

\begin{tabular}{lccccc}
\hline Characteristics/pHs & $\mathrm{pH}=3$ & $\mathrm{pH}=5$ & $\mathrm{pH}=7$ & $\mathrm{pH}=9$ & $\mathrm{pH}=11$ \\
\hline Zeta potential $(\mathrm{mV})$ & 12.91 & 1.44 & -14.56 & -55.7 & -76.04 \\
\hline Particle size $(\mathrm{nm})$ & 8142.8 & 4996 & 14220.4 & 17595 & 25584.4 \\
\hline
\end{tabular}

Figure 2: The zeta potential distribution (a) and $\mathrm{H}_{2}$-TPR profile (b) of the octahedral $\mathrm{NiO}$ sample.

a modular frequency of $250 \mathrm{~Hz}$, and a scattering angle of $15^{\circ}$. The standard errors of the zeta potentials, converted from experimentally determined electrophoretic mobility, were typically $<1.5 \%$ and percent errors were $<5 \%$. To measure zeta potentials, $0.1 \mathrm{wt} \% \mathrm{NiO}$ was dispersed in deionized water and the $\mathrm{pH}$ of the solution was adjusted $3,5,7,9$, and 11 with $\mathrm{HCl}$ or $\mathrm{NaOH}$. The relative molecular diameter size distributions of the various solutions were also measured using this equipment. Zeta potential distributions were obtained by averaging 2 or 3 runs. $\mathrm{H}_{2}$-temperature-programmed reduction (TPR) was conducted as follows. About $0.3 \mathrm{~g}$ of $\mathrm{NiO}$ was pretreated under helium flow $(30 \mathrm{~mL} / \mathrm{min})$ at $700^{\circ} \mathrm{C}$ for $2 \mathrm{~h}$ and then cooled to room temperature. The analysis was carried out using a thermal gravimetric analyzer at $\mathrm{H}_{2}(10 \mathrm{vol} \%) / \mathrm{N}_{2}$ flow rate of $30 \mathrm{~mL} / \mathrm{min}$ and by raising the temperature from room temperature to $800^{\circ} \mathrm{C}$ at $5^{\circ} \mathrm{C} / \mathrm{min}$.

\subsection{Fabrication of Solid Oxide Fuel Cells Using Decalcomania} Method. The decalcomania paper was prepared next. Briefly, two types of commercial and synthesized $\mathrm{NiO}$ were each mixed with YSZ powders at a weight ratio $6: 4$ in a mortar for $1 \mathrm{~h}$ to obtain anode functional layer (AFL) precursor powder. Mixtures were reduced to unique and fine particles $(5 \sim 10 \mu \mathrm{m})$ using a 3-roll ball mill (EXAKT50, German) and a high speed mixer (Thinky centrifugal mixer, Japan), and then a binder (benzene oil) was dropped into the powder mixture (the weight ratio of powder to benzene oil in paste was $58 \sim 66: 42 \sim$
34). The prepared pastes were assembled onto decalcomania sheets (Tullis Russell Coaters, Republic of Korea) using screen printing equipment (DSP-380VS, Nsys, Republic of Korea). Papers were dried at $40^{\circ} \mathrm{C}$ for $24 \mathrm{~h}$ and then detached from decalcomania sheets to use anode functional layer. First, the AFL layer was fabricated onto a ceramic support ( $\$ 20 \mathrm{~mm}$ disk) using the decalcomania coating method and then an electrolyte (YSZ) layer paper was attached to the AFL layer. The layers were pretreated at $400^{\circ} \mathrm{C}$ for $1 \mathrm{~h}$ to remove the organic binder and then cotreated at $1400^{\circ} \mathrm{C}$ for $10 \mathrm{~h}$ at a heating rate of $3^{\circ} \mathrm{C} / \mathrm{min}$. $\mathrm{La}_{0.7} \mathrm{Sr}_{0.3} \mathrm{MnO}_{3} / \mathrm{YSZ}$ paper cathode was fabricated on the YSZ films using the decalcomania method. Finally, the assembled cell was sintered by heating at $1200^{\circ} \mathrm{C}$ for $2 \mathrm{~h}$. Cell 1 was based on commercial $\mathrm{NiO}$ anodes (particle size $0.6 \mu \mathrm{m}$, Sumitomo, Japan) and $\mathrm{NiO}$ anode in cell 2 was synthesized in this study; cell efficiencies were compared. Pt paste (DAD-87, China) was employed as a current collector and a sealing material. After being sealed, cells were tested for power density in an electrical furnace using the four-probe method. The NiO/YSZ anode was reduced in situ at $800^{\circ} \mathrm{C}$. The anode was fed with hydrogen at a flow rate of $500 \mathrm{~mL} \mathrm{~min}^{-1}$ and the cathode was exposed to an oxygen flow of $1,000 \mathrm{~mL} \mathrm{~min}^{-1}$. $I-V$ characteristics and ELS impedance spectra were measured using an SOFC Button Cell Test Station (Nara Cell Tech., Republic of Korea) and an impedance analyzer SI 1260 (Solatron, England) at a frequency range of $1 \mathrm{~Hz}$ to $100,000 \mathrm{~Hz}$ and at an $\mathrm{AC}$ voltage of $20 \mathrm{mV}$. 


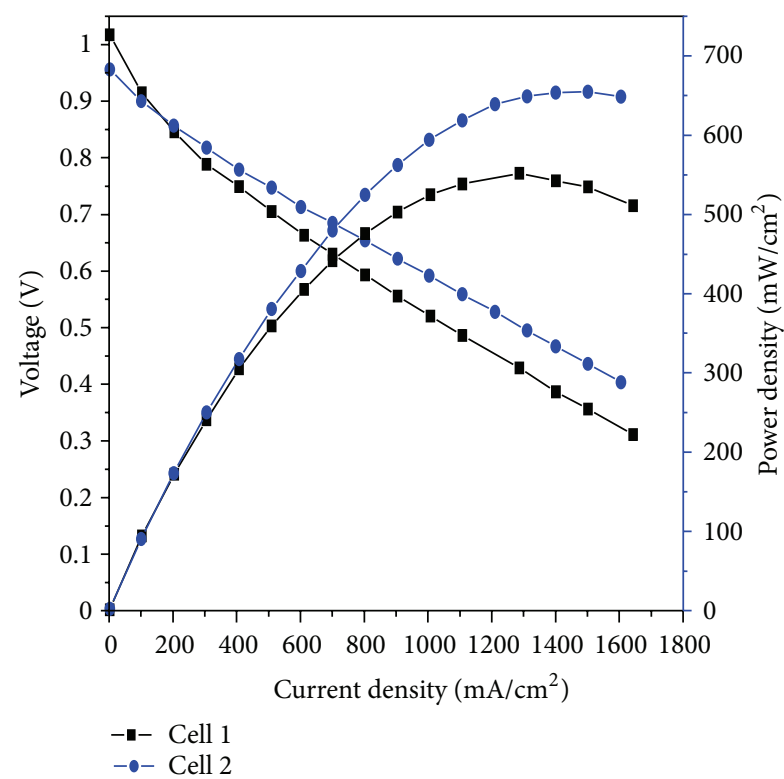

(a)

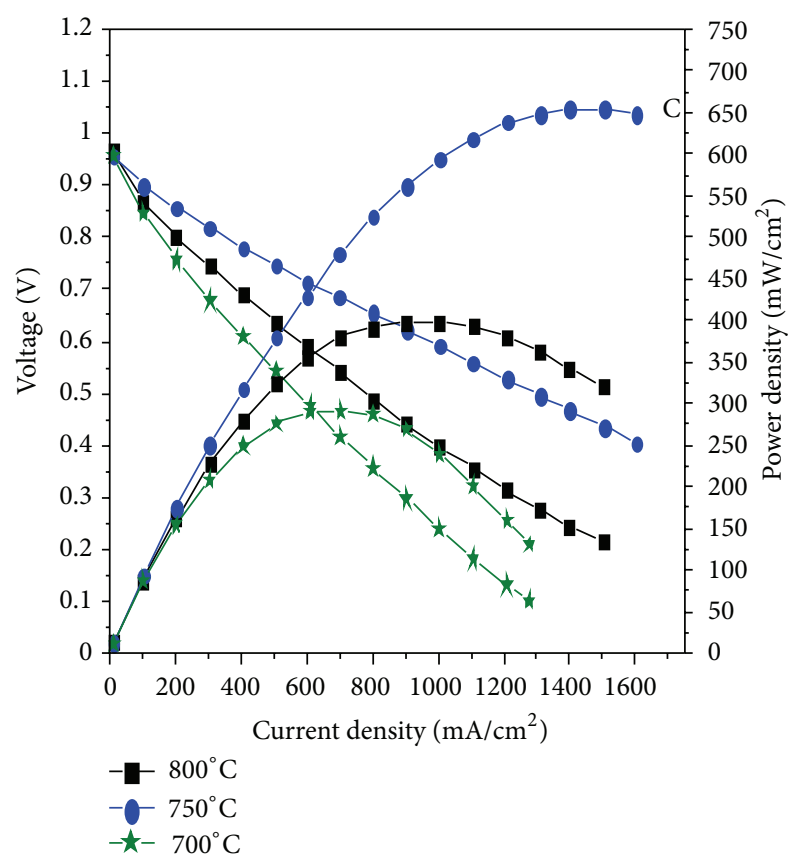

(b)

FIgURE 3: The $I-V$ and power density curves of single cells based on commercial $\mathrm{NiO}$ and synthesized octahedral $\mathrm{NiO}$ anode functional layers (a) at different temperatures (b).

\section{Results and Discussion}

Figures 1(a), 1(b), and 1(c) show the XRD pattern, SEM image, and particle size distribution of an $\mathrm{NiO}$ powder synthesized by microwave treatment. We believe in the microwave chamber that $\mathrm{ROR}$ or $\mathrm{H}_{2} \mathrm{O}$ elimination rapidly induces a combination between each Ni alkoxide or hydroxide. During this reaction, the condensation reaction continues in the absence of any blocking molecules, and the resulting nucleated $\mathrm{NiO}$ can grow in all directions to produce a spherical-shaped $\mathrm{NiO}$. However, the presence of polystyrene induces a selective and competitive condensation reaction at the six terminals of the Ni hydroxide complexes, resulting in an octahedral shape. These results revealed that microwave pretreatment had a significant effect on crystal growth, presumably because microwave treatment processing induces rapid hydrolysis of $\mathrm{Ni}-\mathrm{OH}$ or $\mathrm{Ni}-\mathrm{OR}$ and polycondensation of these. Initial growth leads to a linear chain of $\mathrm{Ni}-\mathrm{OH}$ and the high concentration of $\mathrm{OH}$ ions present leads to crystallization of $\mathrm{NiO}$ possibly because the intermolecular reaction between each $\mathrm{Ni}-\mathrm{OH}$ is higher than the intra-molecular reaction. Due to the complexity of the NiO synthetic method, perfect octahedral $\mathrm{NiO}$ has not been synthesized for SOFCs. Fortunately, we were able to obtain the octahedral $\mathrm{NiO}$ by using the microwave thermal treatment method, as shown in Figure 1(a). The $\mathrm{NiO}$ structure showed peaks at 2 theta $=38.0$, $43.5,63.0,70.0$, and 78.58, which were assigned to the (d111), (d200), (d220), (d311), and (d222) planes, respectively [19]. Line broadening of the peak of the main 200 plane is related to crystallite size. The full width at half maximum (FWHM) of the peak at 2 theta $=43.58$ was estimated using Scherrer's equation [20] $(t=0.9 \lambda / \beta \cos \theta$, where $\lambda$ is the wavelength of incident X-rays, $\beta$ the FWHM height in radians, and $\theta$ the diffraction angle). From this calculation, the crystalline domain size was calculated as $7.2 \mu \mathrm{m}$. Figure $1(\mathrm{~b})$ shows FE-SEM images of the particle shapes of $\mathrm{NiO}$. A relatively uniform octahedral shape and particle sizes in the range $4 \sim 10 \mu \mathrm{m}$ (average size $7.2 \mu \mathrm{m}$ by the particle size analyzer in Figure 1(c)) were observed.

Figures 2(a) and 2(b) depict the influence of $\mathrm{pH}$ on the position of the zeta potential distribution and $\mathrm{H}_{2}$-TPR profile of the octahedral $\mathrm{NiO}$ sample. Aggregated particle sizes in aqueous solution are summarized in the table in Figure 2. The zeta potentials of octahedral $\mathrm{NiO}$ suspensions significantly decreased on increasing $\mathrm{pH}$ (Figure 2(a)). Surface charges changed from positive in acidic solution to negative in alkali solution. The isoelectric point was at $\mathrm{pH} 5.4$ and at this value a large amount of aggregation occurred. Absolute surface charge peaked at $-76.04 \mathrm{mV}$ at $\mathrm{pH} 11$, indicating that the octahedral colloidal $\mathrm{NiO}$ is stable [21]. At this level, it exhibited little aggregation, indicating that reaction sites were present over the surface of the anode material. In addition, we compared the $\mathrm{H}_{2}$-TPR profiles of the two $\mathrm{NiO}$ samples (octahedral and commercial), as shown in Figure 2(b). One $\mathrm{H}_{2}$-TPR peak corresponding to the reduction of the $\mathrm{NiO}$ component was observed. In general, $\mathrm{H}_{2}$-TPR results indicated that (1) the peak area corresponded to hydrogen uptake and (2) the peak at high temperatures corresponded to the chemical reduction. The reduction peaks of the octahedral $\mathrm{NiO}$ sample were gradually shifted more so to lower temperatures than those of the commercial $\mathrm{NiO} . \mathrm{Ni}^{2+}$ ions were reduced to $\mathrm{Ni}^{0}$ at a comparatively low temperature of $330 \sim 430^{\circ} \mathrm{C}$ in octahedral $\mathrm{NiO}$.

Figures 3(a) and 2(b) compare the $I-V$ and power density curves of a single cell based on commercial $\mathrm{NiO}$ (cell 1) and the cell assembled by synthesized octahedral $\mathrm{NiO}$ anode functional layers (cell 2). Maximum power densities 

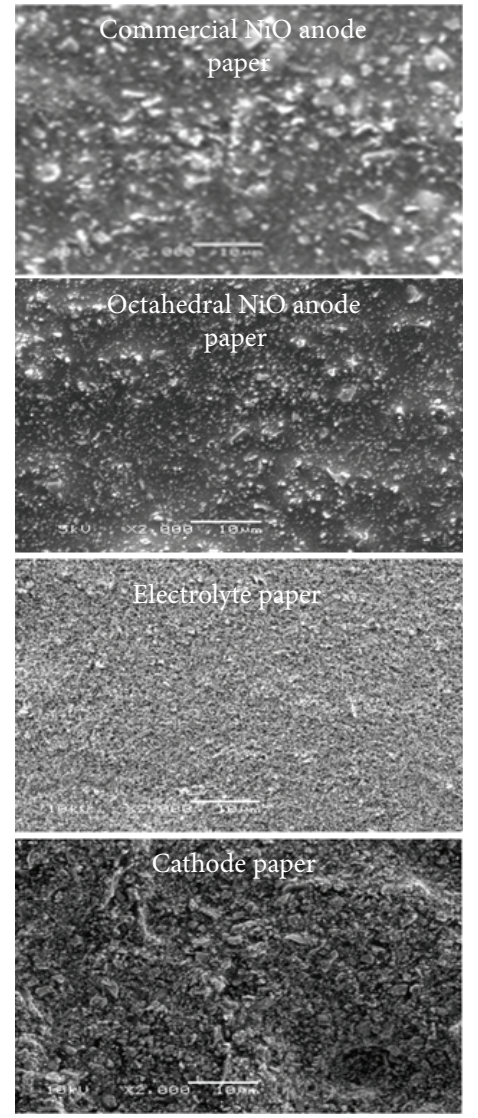

(a)
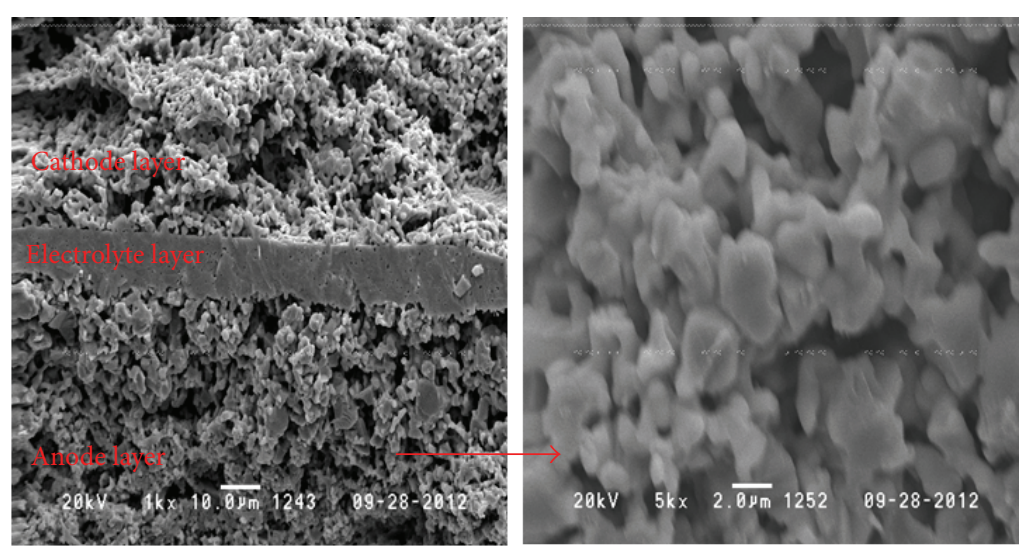

(b) Cell 1
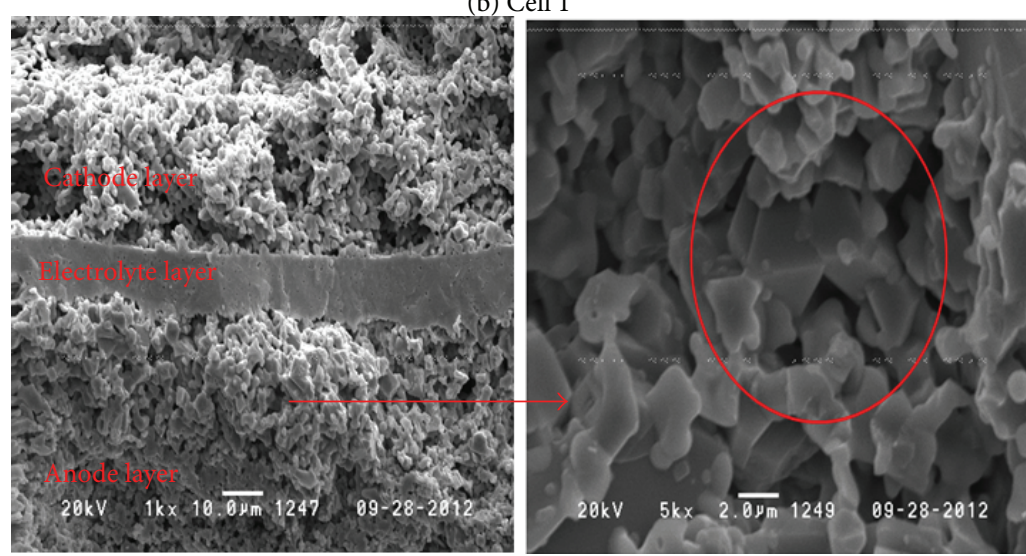

(c) Cell 2

FIGURE 4: FE-SEM micrographs of cells with different anode functional layers after SOFC testing.

in cells 1 and 2 were measured at 551 and $654 \mathrm{mWcm}^{-2}$ at $800^{\circ} \mathrm{C}$, respectively (Figure $3(\mathrm{~b})$ ). Cell performance was significantly improved by the addition of the octahedral $\mathrm{NiO}$ anode functional layer. In Figure 3(b), according to operating temperatures, the maximum power densities on a single type of cell were increased up to 293,401 , and $654 \mathrm{~mW} \mathrm{~cm}^{-2}$ at 700 , 750 , and $800^{\circ} \mathrm{C}$, respectively.

We considered that fuel cell performance differences could be due to different interfacial microstructures.

Figures 4(a) and 4(b) show the SEM micrographs of the cells with different anode functional layers after SOFC testing. The pores in the commercial NiO-AFL (cell 1) are submicron in diameter and the large pores are 2 5 micrometers in diameter. The estimated porosity of the commercial AFL is about 35\%. However, the pores in the octahedral NiO-AFL (cell 2) were smaller than those in commercial NiO-AFL. Large cracks were clearly discernible at the interface between the AFL and the electrolyte layer in the commercial $\mathrm{NiO}$ cell, but no crack was observed in the octahedral $\mathrm{NiO}$ cell. The development of cracks at the AFL/electrolyte layer interface was probably caused by the differential sintering shrinkages of the multiple layers, and thus, the octahedral $\mathrm{NiO}$ particles perhaps better matched the YSZ electrolyte particles in this respect. Additionally the grains between octahedral $\mathrm{NiO}$ particles were well connected in octahedral NiO-AFL cells.
Fewer cracks at the AFL/electrolyte interface result in a lower ohmic cell ASR. Electrochemical impedance spectroscopy (EIS) measurements in open-circuit conditions were used to evaluate the resistance values with respect to operating temperature for the octahedral NiO-AFL cell. Figure 5 shows typical Nyquist plots of cells with an octahedral $\mathrm{NiO}$ anode functional layer, measured at 700,750 , and $800^{\circ} \mathrm{C}$. The intercept with the real axis at high frequency represents the ohmic resistance of a cell (Rohmic), which includes its electrolyte and lead wire resistances and some contact resistance associated with interfaces. The low-frequency intercept corresponds to the total resistance of the cell. Therefore, the difference between the high frequency and low frequency represents the total interfacial polarization resistance $\left(R_{p}\right)$ of the cell [22]. The Rohmic of the cell was almost the same $\left(0.78 \Omega \mathrm{cm}^{-2}\right)$ at all temperatures, but $R_{p}$ was significantly lower at $800^{\circ} \mathrm{C}$ than at 700 and $750^{\circ} \mathrm{C}$. $R_{p}$ reduced from 2.85 to $1.21 \Omega \mathrm{cm}^{-2}$, respectively, with increasing temperature from 700 to $850^{\circ} \mathrm{C}$. Generally, these different resistance values are ascribed to the addition of the anode functional layer, since other parameters, such as electrolyte thickness, cathode material, anode substrate, and sintering temperature, were kept constant. As mentioned above, $R_{p}$ is mainly due to electrolyte and contact resistance. Therefore, a better contact between electrolyte and anode can decrease contact resistance and 


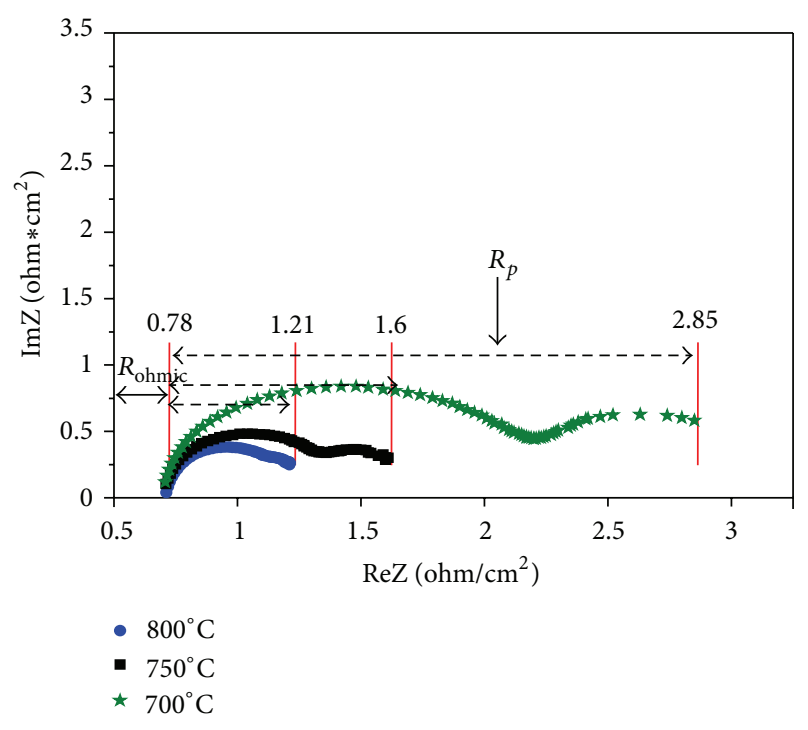

Figure 5: Typical Nyquist plots of cells with an octahedral $\mathrm{NiO}$ anode functional layer at 700,750 , and $800^{\circ} \mathrm{C}$.

reduce total $R_{p}$ for a given electrolyte thickness. At the anode/electrolyte interface for the cell with anode functional layer, the elimination of macropores led to a better contact between electrolyte and the anode, which reduced contact resistance at the anode/electrolyte interface. In this study, the octahedral NiO-AFL cell provided lower $R_{p}$ values due to faster electrochemical reactions at the anode/electrolyte interface.

\section{Conclusions}

This study described the effect of anode functional layer on SOFC performance. Identical single cells, differing only in terms of anode functional layer morphology, were fabricated and tested. Using an octahedral $\mathrm{NiO}$ anode functional layer, fuel cell performance was significantly improved by up to a power output of $100 \mathrm{mWcm}^{-2}$ at $850^{\circ} \mathrm{C}$, due to better contact between the electrolyte and anode. These findings demonstrate cell performance is critically dependent on anode microstructure and that microwave thermal treatment provides an effective means of octahedral $\mathrm{NiO}$ anode materials.

\section{Acknowledgments}

This work was supported by the New \& Renewable Energy of the Korea Institute of Energy Technology Evaluation and Planning (KETEP) Grant funded by the Korea Government Ministry of Knowledge Economy (no. 2010T100100622).

\section{References}

[1] T. Suzuki, Y. Funahashi, T. Yamaguchi, Y. Fujishiro, and M. Awano, "Development of cube-type SOFC stacks using anodesupported tubular cells," Journal of Power Sources, vol. 175, no. 1, pp. 68-74, 2008.
[2] T. Yamaguchi, S. Shimizu, T. Suzuki, Y. Fujishiro, and M. Awano, "Fabrication and evaluation of a novel cathode-supported honeycomb SOFC stack," Materials Letters, vol. 63, no. 29, pp. 2577-2580, 2009.

[3] Y. Yang, G. Wang, H. Zhang, and W. Xia, "Computational analysis of thermo-fluid and electrochemical characteristics of MOLB-type SOFC stacks," Journal of Power Sources, vol. 173, no. 1, pp. 233-239, 2007.

[4] F. Smeacetto, M. Salvo, M. Santarelli et al., "Performance of a glass-ceramic sealant in a SOFC short stack," International Journal of Hydrogen Energy, vol. 38, no. 1, pp. 588-596, 2013.

[5] M. Lockett, M. J. H. Simmons, and K. Kendall, "CFD to predict temperature profile for scale up of micro-tubular SOFC stacks," Journal of Power Sources, vol. 131, no. 1-2, pp. 243-246, 2004.

[6] F. Tietz, H. P. Buchkremer, and D. Stöver, "Components manufacturing for solid oxide fuel cells," Solid State Ionics, vol. 152-153, pp. 373-381, 2002.

[7] J. Will, A. Mitterdorfer, C. Kleinlogel, D. Perednis, and L. J. Gauckler, "Fabrication of thin electrolytes for secondgeneration solid oxide fuel cells," Solid State Ionics, vol. 131, no. 1, pp. 79-96, 2000.

[8] D. Rui, H. Zhang, G. Wang, F. Xiong, and B. Hu, "Fabrication of finely structured silicon-supported SOFC with anode deposited by multi-phase plasma spraying," Journal of Materials Processing Technology, vol. 212, pp. 2193-2199, 2012.

[9] Y. C. Yang, T. H. Chang, Y. C. Wu, and S. F. Wang, "Porous $\mathrm{Ni} / 8 \mathrm{YSZ}$ anode of SOFC fabricated by the plasma sprayed method," International Journal of Hydrogen Energy, vol. 37, pp. 13746-13754, 2012.

[10] L. R. Pederson, P. Singh, and X. D. Zhou, "Application of vacuum deposition methods to solid oxide fuel cells," Vacuum, vol. 80, no. 10, pp. 1066-1083, 2006.

[11] Y. Du, N. M. Sammes, and G. A. Tompsett, "Optimisation parameters for the extrusion of thin YSZ tubes for SOFC electrolytes," Journal of the European Ceramic Society, vol. 20, no. 7, pp. 959-965, 2000.

[12] Q. Yang, J. Sha, X. Ma, and D. Yang, "Synthesis of NiO nanowires by a sol-gel process," Materials Letters, vol. 59, no. 14-15, pp. 1967-1970, 2005.

[13] C. Zhang, J. Zhan, J. Wu, X. Guo, and M. Okido, "Preparation of fibrous nickel oxide particles," Transactions of Nonferrous Metals Society of China, vol. 13, pp. 1441-1445, 2003.

[14] S. M. Tan, S. P. Chai, W. W. Liu, and A. R. Mohamed, "Effects of $\mathrm{FeO}_{x}, \mathrm{CoO}_{x}$, and $\mathrm{NiO}$ catalysts and calcination temperatures on the synthesis of single-walled carbon nanotubes through chemical vapor deposition of methane," Journal of Alloys and Compounds, vol. 477, no. 1-2, pp. 785-788, 2009.

[15] A. M. Reddy, A. S. Reddy, K. S. Lee, and P. S. Reddy, "Growth and characterization of $\mathrm{NiO}$ thin films prepared by $\mathrm{dc}$ reactive magnetron sputtering," Solid State Sciences, vol. 13, no. 2, pp. 314-320, 2011.

[16] C. H. Jung, S. Jalota, and S. B. Bhaduri, "Quantitative effects of fuel on the synthesis of $\mathrm{Ni} / \mathrm{NiO}$ particles using a microwaveinduced solution combustion synthesis in air atmosphere," Materials Letters, vol. 59, no. 19-20, pp. 2426-2432, 2005.

[17] F. Rousseau, S. Awamat, M. Nikravech, D. Morvan, and J. Amouroux, "Deposit of dense YSZ electrolyte and porous NiOYSZ anode for SOFC device by a low pressure plasma process," Surface and Coatings Technology, vol. 202, no. 4-7, pp. 12261230, 2007. 
[18] S. Biswas, T. Nithyanantham, S. N. Thangavel, and S. Bandopadhyay, "High-temperature mechanical properties of reduced NiO-8YSZ anode-supported bi-layer SOFC structures in ambient air and reducing environments," Ceramics International, vol. 39, no. 3, pp. 3103-3111, 2013.

[19] D. Y. Han, H. Y. Yang, C. B. Shen, X. Zhou, and F. H. Wang, "Synthesis and size control of $\mathrm{NiO}$ nanoparticles by water-in-oil microemulsion," Powder Technology, vol. 147, no. 1-3, pp. 113116, 2004.

[20] N. M. Deraz, M. M. Selim, and M. Ramadan, "Processing and properties of nanocrystalline $\mathrm{Ni}$ and $\mathrm{NiO}$ catalysts," Materials Chemistry and Physics, vol. 113, no. 1, pp. 269-275, 2009.

[21] L. Zhang, S. P. Jiang, W. Wang, and Y. Zhang, "NiO/YSZ, anodesupported, thin-electrolyte, solid oxide fuel cells fabricated by gel casting," Journal of Power Sources, vol. 170, no. 1, pp. 55-60, 2007.

[22] Q. L. Liu, K. A. Khor, and S. H. Chan, "High-performance lowtemperature solid oxide fuel cell with novel BSCF cathode," Journal of Power Sources, vol. 161, no. 1, pp. 123-128, 2006. 

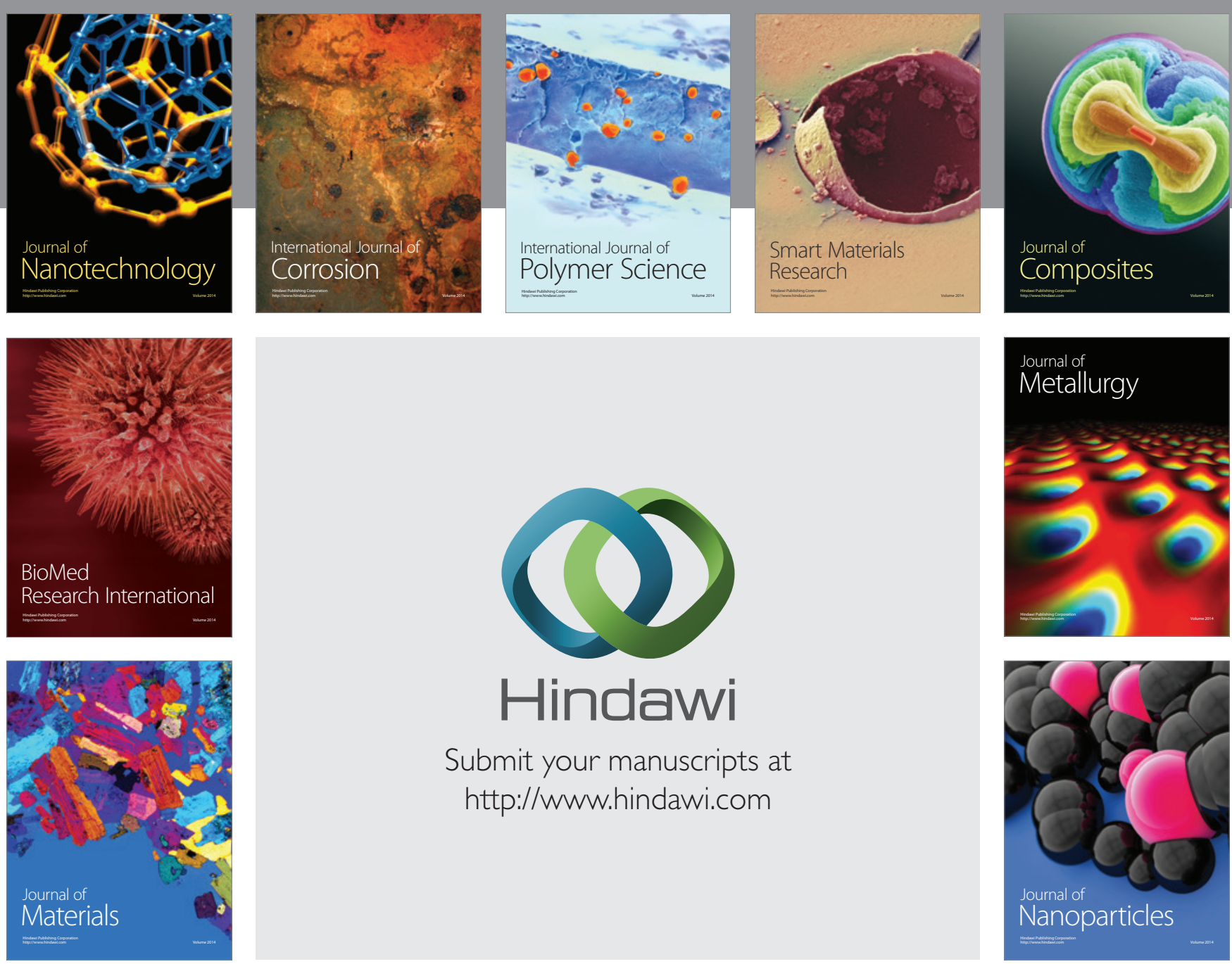

Submit your manuscripts at http://www.hindawi.com
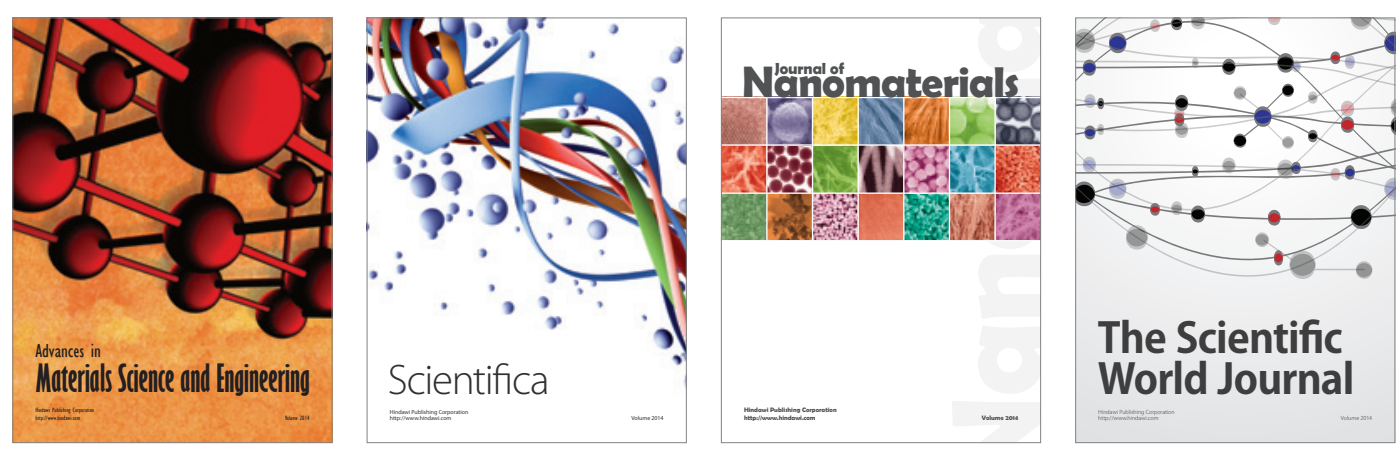

\section{The Scientific World Journal}
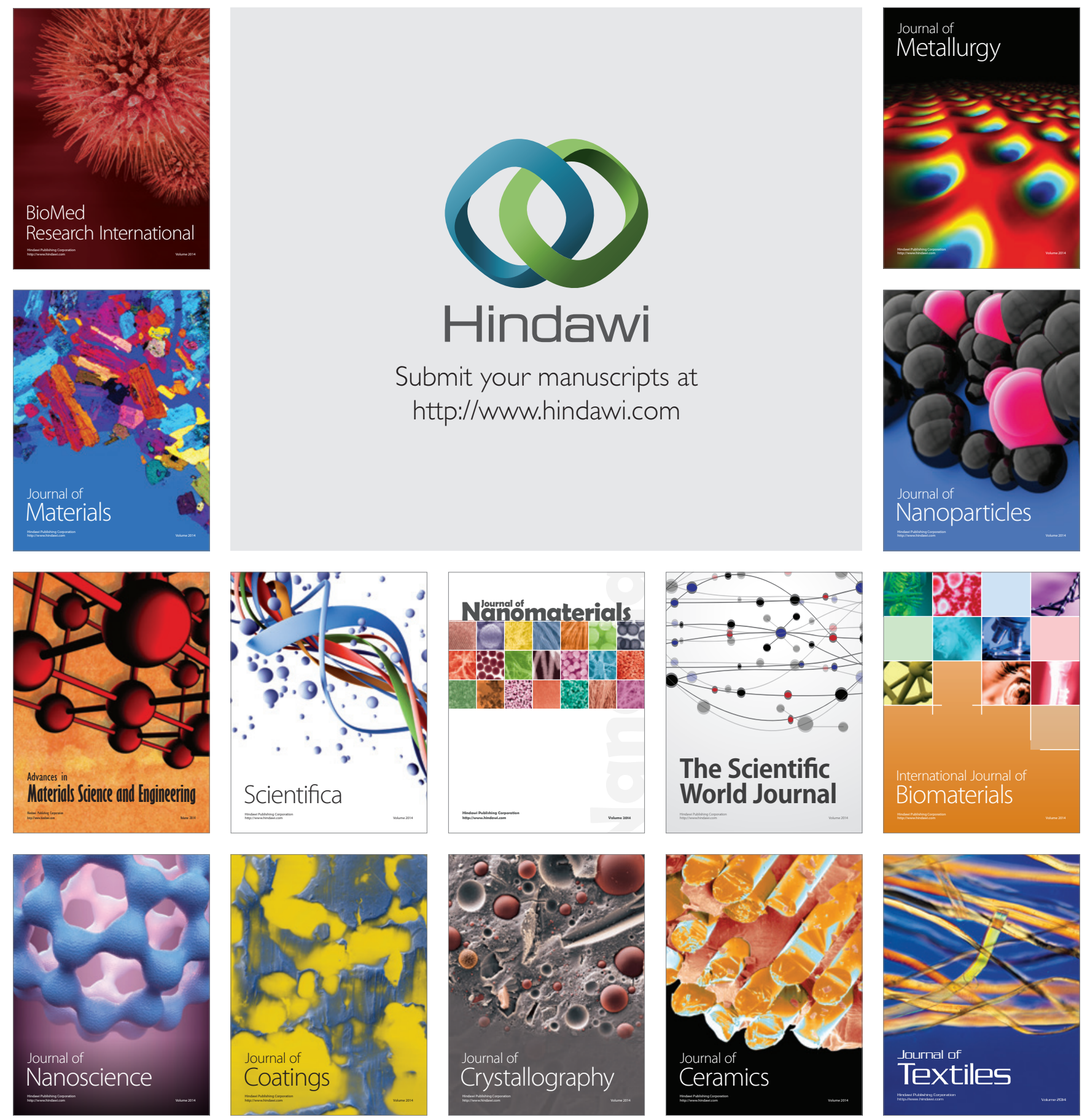